\title{
Islamic orthodoxy-based character education: creating moderate Muslim in a modern pesantren in Indonesia
}

\author{
Imam Mujahid \\ Universitas Islam Negeri Raden Mas Said Surakarta, Indonesia \\ E-mail:imammujahidsolo@gmail.com
}

DOI:10.18326/ijims.v11i2.185-212

\begin{abstract}
Pesantren (Islamic boarding school) has been contributing to building a moderate character for Muslims in Indonesia towards globalization. However, amid the peaceful Islam disseminated in the country, nowadays, a radical Muslim movement challenges this character. This study aims to describe the construction of turats (traditional Muslim virtues), which has been taught in pesantren as an orthodox teaching legacy to create young Muslims with a moderate attitude through character education. It will also highlight how and why character education with Islamic orthodoxy content is necessary to be inculcated in pesantren to produce a moderate Muslim. Qualitative research was employed in this study, with a case study approach. The results demonstrated that moderate character building based on the modernization of turats is derived from the renowned dogma of the ushul figh (traditional Islamic Jurisprudence) and al muhafadhatu 'ala al-qadim as-sholih wal akhdu bi al-jadid al-ashlah (maintaining good tradition and employing the new-better one). Within 24-hour pesantren learning activities, this jargon is disseminated to the students through the concept of Islamic guidance.
\end{abstract}


In this concept, moderate character values infused in the student's activities are rooted to the Quran (Muslim holy book) and Hadits (Prophet's wisdom) as the religious foundation, the founding fathers' vision (historical foundation), the pesantren mission (institutional foundation), and the contextual experience (empirical foundation) as well as the dynamic challenges of the globalization. The entire character education process paves a pivotal way to the moderate Muslim generation creation.

Pesantren ikut berjasa dalam membangun karakter Muslim Indonesia yang moderat guna menghadapi globalisasi. Namun demikian, sekarang, ditengah penyemaian Islam yang damai di negara ini, gerakan Muslim radikal melawan karakter moderat ini. Kajian ini bermaksud untuk menjelaskan bangunan turats (nilai luhur Muslim tradisional), yang diajarkan di pesantren sebagai warisan ajaran ortodoks, untuk mencetak pemuda Muslim yang bersikap moderat melalui pendidikan karakter. Kajian ini juga menjelaskan tentang bagaimana dan kenapa Pendidikan karakter dengan menggunakan muatan ajaran Islam ortodoks itu penting untuk disampaikan di pesantren guna melahirkan Muslim yang moderat. Riset kualitatif digunakan dalam kajian ini, dengan menggunakan pendekatan studi kasus. Hasil kajian menunjukkan bahwa pembangunan karakter moderat berdasarkan modernisasi turats diturunkan dari dogma ushul figh yang terkenal; al muhafadhatu 'ala al-qadim as-sholih wal akhdu bi al-jadid al-ashlah. Selama 24 jam, jargon ini diajarkan kepada para santri melalui konsep bimbingan Islam. Melalui konsep ini, nilai-nilai karakter moderate yang diajarkan kepada para murid dilandaskan pada Quran dan Hadits sebagai pondasi agama, visi pendiri pondok (pondasi sejarah), misi pondok (pondasi institusi), dan pengalaman kontekstual (pondasi empiris) serta tantangan yang dinamis dari globalisasi. Seluruh proses Pendidikan karakter memiliki andil yang penting dalam menciptakan generasi muda Muslim yang moderate.

Keywords: Character education; Islamic guidance; Moderate Muslim; Modern pesantren; Orthodox Islam 
Islamic orthodoxy-based character education: creating moderate Muslim...(Imam Mujahid)

\section{Introduction}

Pesantren consistently attempts to present its identity as a center of tafaqquh fi al-din (understanding Islamic teachings) institution ${ }^{1}$, which maintains turats as an Islamic orthodoxy to build a peaceful Islam². However, Islamic boarding schools are currently encountering global challenges triggered by the development of science, technology, and also social tensions like radicalism and terrorism. For instance, the International Crisis Group (ICG) notes that a prominent pesantren in Central Java has a close link with the South East Asia terrorist network ${ }^{3}$. This situation requires pesantren to responsively adapt to these challenges and to keep building moderate character through their educational process. To anticipate such an ideal, contemporary Islamic orthodoxy defines turats as moral values legacy from the past Islamic civilization for today's Muslims as the religious reference to keep Islam in a moderate way ${ }^{4}$. Turats contain many forms of thoughts, traditions, intellectual works, activities, or noble values that are developed at a certain time for certain purposes. Given the globalization environment, Islamic orthodoxy in the pesantren needs turats modification towards modern character education.

The modernization of pesantren education is required to prepare students for life in the era of globalization, which demands spiritual,

${ }^{1}$ Zamakhsyari Dhofier, Tradisi Pesantren: Studi tentang Pandangan Hidup Kyai, Jakarta: LP3ES, 1994, 21.

${ }^{2} \mathrm{M}$. Abid al-Jabiri, Post Tradisionalisme Islam, Yogyakarta: LKIS, 2000, 45-46. See also, A. M. An-Najjar, Fi Figh al-Tadayyun, Fahman wa Tanzilan (Pemahaman Islam, antara Rakyu dan Wahyu), trans. Bahruddin Fanani, Bandung: PT Remaja Rosdakarya, 1997, 35-36. Hasan Hanafi, Al-Turāth wa al-Tajdid; Mawqifunā min al-Turāth al-Qadim, Beirut: al-Muassasah al-Jam'iyyah li al-Dirāsāt wa al-Nashr wa al-Tawzi', Yogyakarta: Titian Ilahi Press dan Pesantren Pascasarjana Bismillah Press, 2002: 7.

${ }^{3}$ ICG report, https://www.crisisgroup.org/asia/south-east-asia/indonesia/indonesianjihadism-small-groups-big-plans, Jakarta/Brussel, 9 April, 2011. Retrieved at August 2020.

${ }^{4}$ Howard M. Federspiel, "The Muhammadijah: A Study of an Orthodox Islamic Movement in Indonesia”, Indonesia, Number 10 (1970), 74. 
intellectual, and moral preparedness. Today's world dynamics require modernization ${ }^{5}$. Modernity necessitates future-oriented work patterns; however, the modernization of education in pesantrens is designed to preserve the pesantren turats as Islamic orthodoxy.

Pesantren, as the authentic Indonesian Islamic boarding educational institution, has been successful in fostering graduates to have strong characters who can drive a good life and make a positive contribution to the progress of society and the nation ${ }^{6}$. The reason for this achievement is based on the explanation of the late Wahid Hasyim, one of the renowned initial leaders of pesantren, about the purpose of pesantren education being to encourage students to have the virtues of mercy, devotion to God, and the skills necessary for life, including tolerance, respect, and co-existing in a peaceful world? With this knowledge, students can adapt to a multicultural society, be independent, and will not become a burden to others. In this context, pesantren educational process in Wahid Hasyim's tenets will produce both theocentric (divine) and anthropocentric (humanitarian) characters. Theocentric will guide the students to the prophetic needs and virtues, while anthropocentric will lead them to the noble life necessities in the world, emphasizing the ability of students' cognition, affection, and psychomotor.

Zarkasyi, the Kyai (pesantren leader) of Gontor's famous and phenomenal pesantren, emphasizes the pesantren's environment and integral learning model's effectiveness in building character. Integral learning in pesantren, combining theory and practice, enables it to create people with strong character as intended. Character

${ }^{5}$ Koentjaraningrat, Pengantar Ilmu Antropologi, Jakarta: Rineka, 2009, 119.

${ }^{6}$ Nurcholish Madjid, Bilik-bilik Pesantren, Sebuah Potret Perjalanan, Jakarta: Paramadina, 1997, 14.

${ }^{7}$ M.N.K Setiawan, "KH. A. Wahid Hasyim (1914-1953): Tokoh Nasional dari Tradisi Pesantren”, in KH. Wahid Hasyim Sejarah, Pemikiran, dan Baktinya bagi Agama dan Bangsa, Jombang: Pesantren Tebuireng, 2011 38-39. 
is developed through teaching, training, habituation, and coaching ${ }^{8}$. Similarly, Asy'arie argues that the educational product should be fruitful for the benefit of public dynamics ${ }^{9}$. Also, education should teach people about life's realities. The gap between ideality and reality is carefully bridged in pesantren, where character building is a serious goal. So pesantren graduates may be able to moderately sail in the global community.

The Ministry of Religious Affairs (MoRA) of Indonesia stipulates moderate Islam as implementing Islam in a peaceful manner and respecting others away from violence and radical attitudes ${ }^{10}$. Thus, the MoRA emphasizes that moderate Islam is suitable for Indonesians given their multicultural environment. In this country of over $210,000,000$ people, the state recognizes six religions, in addition to the hundred ethnicities, languages, and cultures.

The 24-hour education system and instilling Adab (virtuous attitude) are the keys to pesantren building noble character in students. Adab is linked to the spread of monotheism. This character helps students understand their main duty from God as kholifah fi al-ard (the earth guardians). The 24-hour education system also allows for the inclusion of Islamic orthodoxy character values in all pesantren activities. This system incorporates moderate character education into the personal coaching plan. Also, all elements involved in the pesantren text can run effectively.

Pesantren in various regions modernize their learning systems to meet the needs of the plural society in addition to the two keys mentioned above. For example, the renewal of educational facilities and infrastructure, the use of modern technology and management, and the expansion of the curriculum include secular science such as Math, English, and Citizenship. It is to produce graduates who are experts in

${ }^{8}$ K. Hasib, Pendidikan Karakter, Mau Kemana?, http://www.hidayatullah.com/artikel/ tsaqafah/read/2011/07/15/2201/pendidikan-karakter-mau-kemana.html\#.U8WIbkDKtFs Retrieved at August 2020: 3.

${ }^{9}$ Musa Asy'arie, Pendidikan Sekolah Kita Antirealitas dalam Dinamika Kebudayaan dan Problem Kebangsaan, Yogyakarta: Lembaga Studi Filsafat Islam, 2011, 25.

${ }^{10}$ MoRA, Moderasi Beragama, Jakarta: Litbang Kemenag, 2019, 24-25. 
various scientific fields without abandoning pesantren tradition, religious learning, and the importance of character building ${ }^{11}$.

A combination of Islamic orthodoxy and modern education management influenced the major Islamic boarding schools in Indonesia, including Pesantren Assalaam in Surakarta, Central Java. The combination of these two concepts is expected to produce pesantren graduates who fully comprehend Islamic teachings, are open-minded, and possess superior character. A person with a spiritual, intellectual, and moral balance towards the generation of ulul albab (the intelligentsia), and highly committed to humanity based on devotion to God is recognized. This vision is realized by organizing a quality and competitive Islamic education process to produce rahmatan li alamin (the grace for the universe) generation.

\section{Character building in Islam}

Character, the personal identity that shapes a person's perspective, attitude, and behavior, is developed over time through natural and nurture factors. Inherent in every human being is a natural tendency to love goodness. Character is a person's overall positive combination of various good qualities $^{12}$. The nurture factors aim to develop specific character traits in people through education and social interaction ${ }^{13}$. School plays a vital role in developing human character by nurturing and guiding students' unique character ${ }^{14}$. Character is a complex mix of traits, skills, and actions ${ }^{15}$.

${ }^{11}$ L.C. Scerenko, Values and Character Education Implementation Guide, Atlanta: Departement of Education, 1997, 33.

${ }^{12}$ I. Pritchard, "Character Education: Research, Prospects and Problems", American Journal of Education, Vol. 96, Number 4 (1988), 23.

${ }^{13}$ Ratna Megawangi, Pendidikan Karakter Solusi yang Tepat untuk Membangun Bangsa, Cimanggis: Indonesia Heritage Foundation, 2007, 23.

${ }^{14}$ L. Sudiyono, \& N.W. Karmini, "Character Education Through Social Guidance For Student”, Journal Talent Development Ë Excellence, Vol. 12, No. $1^{\text {t }}$ (2020), 284-298.

${ }^{15} \mathrm{~V}$. Battisch, Character Education, Prevention and Positive Youth Development, Columbia: University of Missouri, 2002, 2. 
In Islam, character is seen as human fitrah (genuine) ${ }^{16}$. All people have their basic character destined by God when they were born. However, along with the growth of human maturity, this fitrah is significantly influenced by several factors, which later determine the basic character 'taken for granted' by God, such as the surrounding environment, social life, and cultural backgrounds. The Prophet Muhammad implies that all human are born innocent. It is their parents who will build them as Christians, Jews, or Majusi ${ }^{17}$.

Regarding the ideal character for Muslims, Islamic teachings urge Muslims to nurture their generation as ummatan wasathan (moderate community), which celebrates multicultural and plural society in the global scope. Therefore, in the pesantren sense, through moderate character and attitude, pesantren students are encouraged to develop a peaceful society, religion, and nation ${ }^{18}$.

\section{Pesantren Assalaam and character building}

Pesantren Assalaam is a nationwide and renowned pesantren in Solo, Central Java, Indonesia. Established in 1985, currently this pesantren nurtures more than 2,000 male and female Junior High School (JHS) and Senior High School (SHS) students. They live in the dormitory on the pesantren campus for 24 hours in an area of 10 hectares. Unlike mainstream pesantren in Indonesia, which are traditional and merely maintain orthodox Islam teachings, pesantren Assalaam is a modern pesantren with an upto-date learning system and infrastructure in addition to the traditional arrangement. Pesantren Assalaam, from its early days, intended to spread moderate and peaceful Islam.

\footnotetext{
${ }^{16}$ QS. Al-Rum: 30.

${ }^{17}$ Shahih Muslim, No. 4803

${ }^{18}$ Azyumardi Azra, Pendidikan Islam: Tradisi dan Modernisasi Menuju Milenium Baru, Jakarta: Kalimah Press, 2001, 45.
} 
The construction of moderate character building in pesantren Assalaam cannot be separated from the virtuous intention of the pesantren founders to produce graduates who can answer global needs and challenges through a modern pesantren education model. Ziemek states a similar opinion that the purpose of pesantren is to build santri's (pesantren student) personality, morals, and to equip them with both Islamic and secular science ${ }^{19}$.

Besides following Islamic orthodoxy in the turats, pesantren Assalaam also builds on sound institutional logic and is future oriented. This policy, according to one of pesantren Assalaam's founding fathers, Kyai Djamaluddin, is based on the Quranic term called wal 'aqibatu lil muttaqin (good luck in the future is only for believers). The term muttaqin is construed as people who always act with a cautious attitude, have thoughtful calculations, consider effectiveness and efficiency, and have a sincere spirit ${ }^{20}$.

Pesantren Assalaam's preference for modernization is also accommodated in the turats as al-muhafadhatu' 'ala al-qadim as-shalih wa al-akhdu bi al-jadid alashlah. In this sense, in its third decade period, pesantren Assalaam has been continuously improving the spirit of modernization in fostering a noble and moderate character. Instead of static, the model of moderate character building currently applied in pesantren Assalaam is consistently dynamic, particularly in contributing to the social benefits of the community, religion, and nation. To support this effort, pesantren Assalaam applies a comprehensive education style in three ways. They are integrating two educational manhaj (systems), enforcing modern concepts, and carrying out integral-holistic education.

First is combining two manhaj derived from the Quranic term majma'ul bahraini (the meeting of the two oceans) of education; this step is executed by disseminating

\footnotetext{
${ }^{19}$ Manfred Ziemek, Pesantren dalam Perubahan Sosial, Trans. Butche B. Soendjojo, Jakarta: Perhimpunan Pengembangan Pesantren dan Masyarakat, 1986, 157.

${ }^{20}$ Majelis Pengajian Islam (MPI), Keassalaaman, Surakarta: PPMI Assalaam, 2011, 23-24.
} 
both the national and pesantren curricula. The National curriculum aims to provide secular knowledge like common public schools, while the pesantren curriculum with its 24-hour life in the dormitory aims at exploring and practicing the attitudes and behaviour following the turats teachings. In this situation, the pesantren environment is believed to be a pedagogical circumstance conducive to learning and character development. Consistent with this tenet, Blocher in Mariyana et al. state that the learning environment is a physical, social, and psychological context in which the individual learns and acquires new behaviors ${ }^{21}$. As santri in pesantren Assalaam are aged between 13-18 years old, they are in the process of maturity regarding the physical and psychological functions and are ready to respond to the stimulation from the surrounding atmosphere. This period is crucial in the process of developing cognitive, language, psychomotor, socio-emotional, and spiritual competencies ${ }^{22}$.

Second is the implementation of modern concepts; besides operating the salaf (traditional) pesantren educational model, pesantren Assalaam conducts the modern one, which is relevant to the current conditions and makes adjustments to the global needs and challenges. In the salaf model, turats are noble values transmitted through generations. In pesantren Assalaam, turats takes form of pesantren's thoughts, traditions, strategies, and values.

Despite the high competition in the Indonesian education system, the modernization of pesantren Assalaam attracts Indonesian Muslims. Fananie, one of the founders of the nation-wide Gontor pesantren, argues that modernity is not rationality that denies religion. Fananie defines modernity as a spirit of progress and adaptability, while maintaining Islamic values that emphasize character development ${ }^{23}$.

Third is practicing an integral-holistic education system; pesantren Assalaam teaches students to think comprehensively and to realize that they are part of the broader community. In addition, through this system, all students' human aspects

\footnotetext{
${ }^{21}$ R. Mariana et. al., Pengelolaan Lingkungan Belajar, Jakarta: Kencana, 2010, 17.

${ }^{22}$ Abdul Wahid, Menggerakkan Tradisi: Esai-Esai Pesantren, Yogyakarta: LkiS, 2001, 51.

${ }^{23}$ R.Z. Fananie, Pedoman Pendidikan Modern, Jakarta: Fananie Center, 2010, 65.
} 
are forged holistically, including academic, spiritual, emotional, social, creative, and physical potential ${ }^{24}$. For instance, integral-holistic education is generally carried out through the process of $t a^{\prime}$ lim (teaching), tarbiyah (education), and ta'dib (moralcharacter building). Ta'lim leads to the development of knowledge and skills needed by students as a means to navigate life. Tarbiyah gradually guides students to having a good basic character through measurable guidance. And, ta'dib is a role-modelling educational process that emphasizes the implementation of moral knowledge for grounding the character establishment. For pesantren teachers, knowledge can only be inculcated into students with good character towards science, and science can never be understood by students without a civilized manner. Al-Attas explains the concept of the integral-holistic education system in pesantren as creating good people, that is, a person who knows the Lord and the prophet, puts knowledge in an honorable place, and understands the human duty as the khalifah fil ardhi properly $y^{25}$. In short, good people are understood as humans who have various virtues in themselves ${ }^{26}$.

Based on the educational system described above, pesantren Assalaam intends to translate the vision of the pesantren by constructing a strong foundation for the moderate character of its students. For this, the pesantren develops santri's character through comprehensive, concepted, and measurable programs, starting from the formulation of the main and basic character values, the 24-hour activities for santri, to the character building strategy.

\section{Main and basic character value}

It is the initial step towards building students' moderate character in pesantren Assalaam, which covers the consideration of religious, historical, institutional, empirical, as well as social, scientific, and technological

\footnotetext{
${ }^{24}$ Ratna Megawangi, Pendidikan Karakter Solusi yang Tepat untuk Membangun Bangsa, Cimanggis: Indonesia Heritage Foundation, 2007, 23.

${ }^{25}$ Syed M.N. Al-Attas, Islam and Secularism, Kuala Lumpur: ISTAC, 2003, 150.

${ }^{26}$ Adian Husaini, "Pendidikan Karakter Berbasis Ta'dib", Tsaqafah Jurnal Peradaban Islam, Volume 9, No. 2 (2013), 392.
} 
aspects. In this case, the Quran and Hadits as religious facet become the primary guidelines. Quranic teachings on character values are further explained and exemplified by the Prophet through his prophetic mission of completing human morals. Furthermore, historical and institutional reasons, which are the founding fathers' dream and the pesantren's vision respectively, essentially underpin the formulation of the character values. These entire parts are called internal factors. The external components consist of the best practices of other pesantren as the empirical basis and global challenges and dynamics as the social and scientific premise. The combination of internal and external elements makes character building feature in pesantren Assalaam in a moderate way.

Pesantren Assalaam formulates santri's moderate character in five basic santri abilities, which are also called Keassalaaman (Assalaam values). They are science and technology, tafaqquh fi al-din, akhlaqul karimah (noble morality), Islamic da'wah (call for Islam), and leadership. All activities programmed in the pesantren have to use Keassalaaman as the reference and guidance.

Science and technology-oriented characters occupy the first position based on the teachings of Islam, which strongly emphasizes the importance of knowledge and raising the level of knowledgeable people, as mentioned in the Quran chapter Al-Mujadilah (the Debater) verse 11. Through science and technology, students of pesantren Assalaam are taught to understand and contextualize the verses of the Quran in real plural life. For instance, tabayun (clear) and hanif (distinct) values in gaining knowledge received great attention to be disseminated among students. Tabayun is a habit of clarifying unclear information, while hanif is a persistent attitude to investigating the truth through empirical evidence, not merely based on gossip. One of the activities that support tabayun and hanif attitudes is the work of the CASA (Santri Assalaam Astronomy Club), which, instead 
of being involved in an annual protracted debate among Indonesian Muslims to determine the first day of fasting in the month of Ramadan, is directly involved in the process of determining this time by observing the sunset at the campus observatory. This process also means that science and technology are necessary for students. Locke in Lickona argues that superior civilization is inseparable from the core values developed by the country, including reason, individual rights, and science and technology ${ }^{27}$.

Tafaqquh fi al-din character clearly distinguishes between public and pesantren students in terms of Islamic teaching understanding. In this case, students are accustomed to combining science, thought, memorizing, and studying hard effort in an Islamic manner. Through this character, students are expected not to have the qualities of faith which are un-Islamic like being radical and doing violence.

Akhlaqul karimah character intends to forge students' attitudes and behaviors following Quranic manners, Hadits wisdom, and society's moderate customs. It is a personal quality manner that underlies all students' activities and the moral differentiator among them, which consists of the moral values of piety, sincerity, modesty, independence, discipline, cleanliness, and humility. By internalizing this character, the students are oriented to being good citizens in the public sphere.

Da'wah Islamiyah is the student's character to call for Islam constantly to the people employing local customs which have been adapted to Islamic teachings. Pesantren Assalaam students must seriously practice and preach Islamic teachings to society. To endorse this program, pesantren Assalaam also provides students with modern communication and presentation skills.

Leadership is a character nurtured specifically for students to become

${ }^{27}$ T. Lickona, Educating for Character, How Our Schools Can Teach Respect and Responsibility, New York: Bantam Books, 1992, 11-12. 
leaders in the future in every scope and at every level. By disseminating this character, pesantren Assalaam graduates are directed to take part as national and global problem solvers. Several activities related to the moderate leadership character infusion are created in pesantren Assalaam, such as scouting, students' organization, and various sports clubs. Apart from this program, pesantren's life generally emphasizes the turats jargon; ibda' bi nafsik (begin with yourself) to be practiced by the students in every activity before commanding others. The successful self-leadership practice will influence significantly the success of leading others in the plural community. Regarding this opinion, Prophet Muhammad has transmitted a precious leadership model, including difficulties and challenges, to leading people successfully and making him the most influential person in the world ${ }^{28}$. The way pesantren Assalaam develops leadership character is in line with House's argument that to build an ideal leadership prototype, behavior, values, attitudes, and personality are pivotal aspects to be embedded ${ }^{29}$.

Based on the above explanation, Keassalaaman constructs positive and moderate characters for the students, which will sharpen their intellectual, spiritual, and emotional development, physical and kinesthetic building, and affective and creativity establishment. Compared with various concepts on character building values, Keassalaaman has similar intersections with a common renowned motto of the Indonesian pesantren of Panca Jiwa Pondok (five pesantren spirits), the prophetic ideal character of the Prophet Muhammad, government concept postulated in the National Development Goals (NDG), and UNESCO principles of togetherness, cooperation, and the desire to develop together with the world community. The summary of this intersection is as shown in table 1 .

\footnotetext{
${ }^{28}$ Muhammad Syafi'i Antonio, Muhammad SAW the Super Leader Manager, Jakarta: Tazkia Multimedia \& Pro LM Centre, 2007, 63.

${ }^{29}$ R.J. House, Culture Leadership and Organizations: The Globe Study of 62 Societies, California: Sage Publications, 2004, 59.
} 
IJIMS: Indonesian Journal of Islam and Muslim Societies, Volume 11, Number 2, December 2021: 185-212

Table 1. The Concepts comparison among character building values

\begin{tabular}{|c|c|c|c|c|}
\hline Keassalaaman & $\begin{array}{c}\text { Panca Jiwa } \\
\text { Pondok }\end{array}$ & $\begin{array}{c}\text { The } \\
\text { Prophetic }\end{array}$ & The NDG & $\begin{array}{l}\text { UNESCO } \\
\text { Principles }\end{array}$ \\
\hline $\begin{array}{l}\text { - Insightful of } \\
\text { Science and } \\
\text { Technology, } \\
\text { - Tafaqquh Fi } \\
\text { al-din } \\
\text { - Akhlaqul } \\
\text { Karimah } \\
\text { - Islamic } \\
\text { da'wah } \\
\text { - Leadership }\end{array}$ & $\begin{array}{l}\text { - Sincerity } \\
\text { - Simplicity } \\
\text { - Be } \\
\text { Independent } \\
\text { - Ukhuwah } \\
\text { Islamiyah } \\
\text { (Islamic } \\
\text { Brotherhood) } \\
\text { - Freedom }\end{array}$ & $\begin{array}{l}\text { - Sidiq } \\
\text { (righteous) } \\
\text { - Amanah } \\
\text { (trustworthy) } \\
\text { - Fathanah } \\
\text { (intelligent) } \\
\text { - Tabligh } \\
\text { (Preaching) }\end{array}$ & $\begin{array}{l}\text { - Religious } \\
\text { - Honest } \\
\text { - Tolerance } \\
\text { - Discipline } \\
\text { - Hard work } \\
\text { - Creative } \\
\text { - Independence } \\
\text { - Democratic } \\
\text { - Curiosity } \\
\text { - Nationalism } \\
\text { - Appreciate } \\
\text { - Achievement } \\
\text { - Networking } \\
\text { - Love peace } \\
\text { - Nerdy } \\
\text { - Eco-friendly } \\
\text { - Social Care } \\
\text { - Responsible }\end{array}$ & $\begin{array}{l}\text { - Peace } \\
\text { - Appreciation } \\
\text { - Love } \\
\text { - Tolerance } \\
\text { - Honesty } \\
\text { - Humble } \\
\text { - Cooperation } \\
\text { - Happiness } \\
\text { - Responsible } \\
\text { - Modesty } \\
\text { - Freedom } \\
\text { - Unity }\end{array}$ \\
\hline
\end{tabular}

Source: compiled by author from Sirah Nabawiyah (History of the Prophet), Keassalaaman book, Indonesian Government policy on NDGs, and UNESCO principles.

In disseminating the values in table 1, pesantren Assalaam makes a serious effort by trying to habituate them to the students consistently and continuously, as instilling moral values is a lifelong business. Sargent and Williamson define moral values generally as a collection of longlasting desires, which individuals or groups try to achieve honestly and continuously ${ }^{30}$.

In daily practice, the main moderate character values developed at

${ }^{30}$ Sargent \& S. William, Social Psychology: An Introduction to the Study of Human Relations, New York: Ronald Press, 1958: 244. 
pesantren Assalaam as in table 1 are classified into more specific forms as follows; (1) Science and technology-oriented characters are fathonah, nerdy, freedom, and curiosity, (2) Characters of tafaqquh fi al-din covers religious, fathanah, nerdy, and curiosity, (3) Characters of Akhlaqul Karimah to include sincerity, modesty, honesty, friendship, care for the environment, peace, and humility; (4) Islamic da'wah consist of tabligh, ukhuwah Islamiyah, tolerance, peace, and unity; (5) Leadership character contains independence, modesty, freedom, discipline, hard work, democracy, nationalism, responsibility, respect, tolerance, honesty, humility, and unity.

\section{Pesantren 24-hour activity cycle}

To provide a conducive atmosphere for instilling moderate character values in the students, pesantren Assalaam designed the 24-hours daily activities program, including various sports clubs, many kinds of religious study clubs, and several student organizations. During this period, the students' attitudes and behaviors are under the surveillance of the teachers. Al-Attas states that a conducive environment is what shapes the behavior and the character of students ${ }^{31}$. Similarly, Lewin in Gunarsa proposed a field theory about the environment and its effect on personal attitudes that is $\mathrm{B}=\mathrm{F}$ (P.E.), means that behavior (B) is a function $(\mathrm{F})$ of the person $(\mathrm{P})$ and the environment $(\mathrm{E})^{32}$.

Given such circumstances and daily life cycles, students are urged to think, to behave, and to conduct themselves within Keassalaaman values guidance, which will be useful to help them to interact with multicultural communities. In following the vast, various activities within 24 hours, some students sense an uncomfortable feeling. However, they confessed that the programs will benefit them in the future as young Muslims with

\footnotetext{
${ }^{31}$ Syed M.N. Al-Attas, The Concept of Education in Islam, Petaling Jaya: ABIM, 1980, 368.

${ }^{32}$ S.D. Gunarsa, Konseling dan Psikoterapi, Jakarta: PT BPK Gunung Mulia, 1992, 36.
} 
a distinctive character. Ali, a male student at SHS, stated as follows:

"I am really bored and tired. But, as Muslims, we have to be strong both physically and mentally. We are the guardians for all creatures in this earth as mandated by God, Allah. [pesantren] Assalaam tries to prepare us for this."

The Kyai of pesantren Assalaam agrees with Ali's statement above as the pesantren activity cycle is created based on the long Indonesian pesantren empirical experience. He explains below:

"Along the Indonesian history, pesantren alumni were able to take part in developing peaceful and civilized society. It is because for 24-hours they were forged seriously in the pesantren to provide them a strong, qualified character that is noble and humble and is expected to involve in protecting all humankind."

One of the ultimate goals of pesantren Assalaam activity cycle is to follow Prophet Muhammad's instructions as recorded in the turats. That is, innamaa bu istu li utammima makaarima al-akhlaq (actually I was sent to complete the noble morals), which means building a person with akhlaqul karimah character. The Prophet lived a hard and problematic life before he could build a perfect akhlaqul karimah (noble morals) successfully. Regarding difficult life situations as a factor in building character, Maxwell in Huda state that character is not a gift, but is built gradually with thoughts, words, real deeds, habituation, courage, competition, and tough struggle ${ }^{33}$.

\section{Character building strategy}

Pesantren Assalaam sets up four character-building strategies, including the socialization of character values, learning activities, personal development activities, and conditioning. First, the socialization of character values supports the efforts of character building based on students' personalities.

\footnotetext{
${ }^{33}$ M. Huda, "Pendidikan Karakter dalam Sebuah Festival", Jawa Pos, 7 Juli 2010.
} 
This is in line with the opinion of Lickona's take, which states that to produce good character, character education must promote core ethical values as a foundation ${ }^{34}$.

Socialization activities are conducted in general and particular ways. The general pattern is a creation to socialize moderate character dissemination through symbols, mottos, hymns, and the march of the pesantren. Through this method, the students know the meaning behind symbols and expressions that contain character values developed at the boarding school. Pesantren Assalaam's symbol and motto are displayed in various strategic places, and its hymns and march, which are always sung at every official ceremony, continuously remind all pesantren stakeholders of the character values being built. While the special pattern is pesantren Assalaam's effort to socialize moderate character values through many kinds of activities that are specifically designed for this purpose, such as spiritual nature observation, khutbah ta'aruf (induction day), halaqoh (study circle), routine Quranic recitation, and outbound.

In the socialization step, Keassalaaman education and training is held by the Majelis Pengajian Islam (Islamic Study Council) foundation, pesantren Assalaam's patron, which must be followed by school leaders, teachers, and staff to refresh the disseminated moderate character values.

Second, pesantren Assalaam constructed learning activities using contextual and inquiry approach. This approach demands students to get involved in the entire learning process, such as planning, sharing ideas, collaborating, exploring, and linking subject matter to real situations. In addition, the inquiry approach ultimately produces meaningful and comprehensive outcomes, including cognitive (knowledge), affective (attitude), and psychomotor (behavior). In this regard, students will become

\footnotetext{
${ }^{34}$ T. Lickona, E. Schaps, \& C. Lewis, 11 Principles of Effective Character Education, Washington: Character Education Partnership, 2010: 54.
} 
proficient in knowledge as they are encouraged to have a high curiosity, and, on top of that, they will sturdily internalize a moderate character. This is in line with the concept of tasywiq, a method in the turats that can increase the enthusiasm for learning and high curiosity, as well as being curious about knowing the answers and the secrets behind the material presented. Tasywiq provokes students to be more enthusiastic, study hard, and examine everything ${ }^{35}$.

According to the researcher's direct observations in the classroom, the contextual and inquiry approach are effective because of several factors: (1) professional teachers who understand the concept of integrated learning and experience, and steadily update their thematic learning models; (2) complete learning facilities, media, and resources; and (3) the learning process runs naturally, and emotionally close to the students.

In pesantren Assalaam, moderate character building is not developed through specific subjects. This character is instilled in students by combining existing national and pesantren subjects. In this sense, students recognize and internalize the values contained in the teachers' subjects, both explicitly and implicitly, and can apply them in daily life. Similarly, the Indonesian Education University Pedagogical Study Center develops substantive and reflective learning subjects that foster character development ${ }^{36}$.

In the pesantren Assalaam context, substantive learning relates directly to the moderate character values to the material substance, including pesantren and national subjects, such as Aqidah (the faith), Akhlaq (morals), Fiqh (Islamic jurisprudence), Quran-Hadits, History of Islamic Culture, and $P P K n$ (Citizenship). Reflective learning is integrated into all subjects at all

\footnotetext{
${ }^{35}$ Muhammad Syafi'i Antonio, Muhammad Saw The Super..., 203.

${ }^{36}$ D. Kesuma, C. Triatna, \& J. Permana, Pendidikan Karakter, Kajian Teori dan Praktik di Sekolah, Bandung: PT Remaja Rosdakarya, 2011, 113.
} 
levels of education, which intends to take the lessons behind the subject materials. For example, the nature of the creation of materials in Science subjects may produce spiritual and high curiosity characters in students.

Mulyasa states that promoting moderate character in the classroom is in line with the 2013 national curriculum. He also states that students' attitudes, competencies, and character can be developed by: (1) encouraging them to apply the concepts, understandings, competencies, and character they learn in school in their daily lives and (2) using the most appropriate method, so they feel comfortable with their personal attitudes ${ }^{37}$.

The strong emotional connection between students and teachers is another important factor in the development of moderate character. Students regard teachers not only as teachers of knowledge and skills, but also as parents, brothers, and friends who provide valuable advice, motivation, and inspiration. Aside from providing course materials, teachers always motivate and encourage students. Motivation is the reason for the action ${ }^{38}$.

Third is personal growth activity, which aims to foster students' interests, talents, hobbies, and potential. Thus, the pesantren's moderate character, along with other supporting characters, will be created. Personal development activities are offered at Pesantren Assalaam, both mandatory and optional. Obligatory activities include scouts, muhadharah (speech), muhadatsah (Arabic conversation), tazwidul mufrodat (learning Arabic), and halaqoh. Among the selected activities are scientific workgroups, martial arts, sports, arts and skills, computer clubs, astronomy clubs, journalistic groups, and nature lover clubs.

The significant of this process lies in the dynamic activity environment of the pesantren. Environment is pivotal in sharping individual character

${ }^{37}$ E. Mulyasa, Pengembangan dan Implementasi Kurikulum 2013, Bandung: PT Remaja Rosdakarya, 2013, 102.

${ }^{38}$ G.R. Lefrancois, Theories of Human Learning, Kro's Report, California: Brook/Cole Publishing Company, 1995, 159. 
as reflected in the behavioristic theory, a man grows to what he is made to be by his environment, a person grows into what is formed by the environment ${ }^{39}$. It means the more dynamic the activity, the stronger the character instilled to the students will be accepted.

Fourth is conditioning, which is one of the pesantren's efforts in shaping the santri's character through conducive atmosphere engineering, including the implementation of a disciplined life (al-indhibath), habituation of positive attitudes (as-Sajiyyah), and the creation of good culture (an-nadzhmu al-ma'had). The conditioning will pave a way to the students' distinctive ways of thinking, attitudes, and behaviors, which will benefit them during the educational process in the pesantren and in the further broader, plural society.

The first step in conditioning at pesantren Assalaam is discipline. It is taught to students as conscious and serious obedience. They must fulfill their obligations and follow the school's tibsar (basic rules). For the inculcated character to run smoothly and solidly, pesantren discipline is required. It also aims to maintain student order and show teachers' responsibility in guiding students 24 hours a day to achieve the pesantren's goals. Pesantren Assalaam enforces religious, attitude, educational, and organizational discipline in Arabic and English. According to Skinner, cited in Feist \& Feist, human behavior is mostly learned through operant conditioning, with reinforcement to the response as its key ${ }^{40}$.

A moderate character is built during conditioning. Students learn moderate values through familiarization. It is a pre-character building step in the pesantren. Consistent positive daily life experiences for students. Positive experiences lead to positive moderate character values. The santri are encouraged, trained, and habituated to the desired behaviors ${ }^{41}$. For

\footnotetext{
${ }^{39}$ S.D. Gunarsa, Konseling dan Psikoterapi, Jakarta: PT BPK Gunung Mulia, 1992, 192.

${ }^{40}$ J. Feist, \& G.J. Feist, Theories of Personality, (Sixth Ed), New York: McGraw-Hill, 2006, 442.

${ }^{41}$ M. Surya, Teori-teori Konseling, Bandung: Bani Quraisy, 2003, 18.
} 
instance, people of different tribes and nations are created by God, so students must respect others. Thus, it is a strict requirement in the pesantren that students pray to Him five times a day.

There are two types of pesantren Assalaam habituation: routine and incidental. Routine habituation involves planned activities, while incidental habituation involves students in specific situations. An example of a routine habituation activity is class study every night. To maintain the value of togetherness, students must assist each other in completing school assignments that are still unclear. The government is facilitating an interfaith dialogue.

Pesantren culture is an important factor that influences the conditioning step. Pesantren students have moderate characters because of a positive behavior inherited from previous generations. Pesantren cultures include role model, reading, queueing, and competition cultures.

Personal and environmental cultures are created as a model for others. This practice focuses on teachers modeling virtuous behaviors and attitudes for students. In fact, role models shape human character. Pesantren Assalaam's role modelling culture includes punctuality, good attire, queueing, empathy, tolerance, and leadership.

Role-playing exposes students to a lot. Their teachers' and pesantren leaders' attitudes and behaviors are clearly visible. In a behavioral sense, role modeling is similar to social modeling. According to this theory, people can learn new behaviors by imitating existing social models ${ }^{42}$.

In the turats, role model is viewed as a notable influence on human character, therefore God, Allah almighty appointed the Prophet as the main role model for humankind. Allah says explicitly in the Quran, Al-Ahzab (the punishment) chapter, verse 21: "There has certainly been for you in the Messenger of Allah an excellent pattern for anyone whose hope is in

${ }^{42}$ M. Surya, Teori-teori Konseling..., 19. 
Allah and the Last Day and [who] remembers Allah".

Reading culture is directly related to the Quran's turats. The first verse of the Quran in the al-Alaq (blood clot) chapter revealed to Muhammad was about reading. Iqra' (read) in the name of Allah. Reading culture in pesantren Assalaam will help students learn and broaden their perspectives. Reading habit also helps students improve their intellectual capacity and ability to absorb Keassalaaman. Reading culture is also a good way to kill time. The Indonesian pesantren has a famous turats phrase: khairu jaalisin fi zamaani kitaabun (the best sitting friend is a book).

Pesantren Assalaam has limited facilities for over 2,000 students. As a result, students must queue for almost everything, including taking a bath, eating three times a day, and paying tuition at the campus bank. Lessons on time management, patience, respect for others, discipline, tolerance, cooperation and honesty are taught through queuing culture.

Competition culture encourages students to excel and to have strong and fair character through school competitions. In addition, there are small and large scale academic and dormitory activities such as English and Arabic speech, room cleanliness, art and skill competitions as well as scouting. The Kyai and pesantren teachers celebrate by rewarding the winners. Muslich's Noah says:

"The habit of giving appreciation will build an environment for the flourishing of quality achievers. If the environment itself does not support a person with achievements, then it will continue to be negative" ${ }^{43}$.

Pesantrens' moderate character-building process based on Islamic orthodoxy values. In Brigham (1991) ${ }^{44}$, Kelman describes three processes of change in the formation of attitudes that lead to behavioral changes.

\footnotetext{
${ }^{43}$ M. Muslich, Pendidikan Karakter: Menjawab Tantangan Krisis Multidimensional, Jakarta: Bumi Aksara, 2011, 161.

44J.C. Brigham, Social Psychology, New York: Harper Collins Publisher Inc., 1991.
} 
The three are: acquiescence, identification, and Compliance occurs when a person receives external influence, such as a positive reaction from a person or group of people. The pesantren habituation and culture activities reflect identification and internalization. Identification happens when someone is influenced to keep good relations with others. Internalization takes place when a person's behavior is influenced by a similar value. Suwija believes character education is a lifelong process towards ideal human beings ${ }^{45}$. Therefore, character education requires a role model and to be nurtured from early childhood to the adult phase.

Using pesantren Assalaam model of moderate character building will help students develop a collective perspective and attitude, which is the foundation of a cultural value system. In this sense, the santri's cultural value system is both a guide and a driver ${ }^{46}$.

The study concludes that disciplinary activities, habits, and pesantren culture in pesantren Assalaam are comprehensive and integral strategies in fostering moderate character development. Organising activities and creating a conducive environment are the first steps. Thus, moderate character building includes moral indulgence and moral implementation as a form of internalization of character values in students' daily behavior (See table 2).

${ }^{45}$ I.N. Suwija, I.M. Darmada, I.N. Mulyawan, \& W. Suryasa, "Character Education Value of Ending King Sexual Cruelty on Ni Dyah Tantri Story”, Talent Development Ë Excellence, Vol. 12, No. 2 (2020), 737-745.

${ }^{46}$ E. Wynne \& H. Walberg (Eds.), Developing Character: Transmitting Knowledge, Posen: ARL, 1984, 13. 
IJIMS: Indonesian Journal of Islam and Muslim Societies, Volume 11, Number 2, December 2021: 185-212

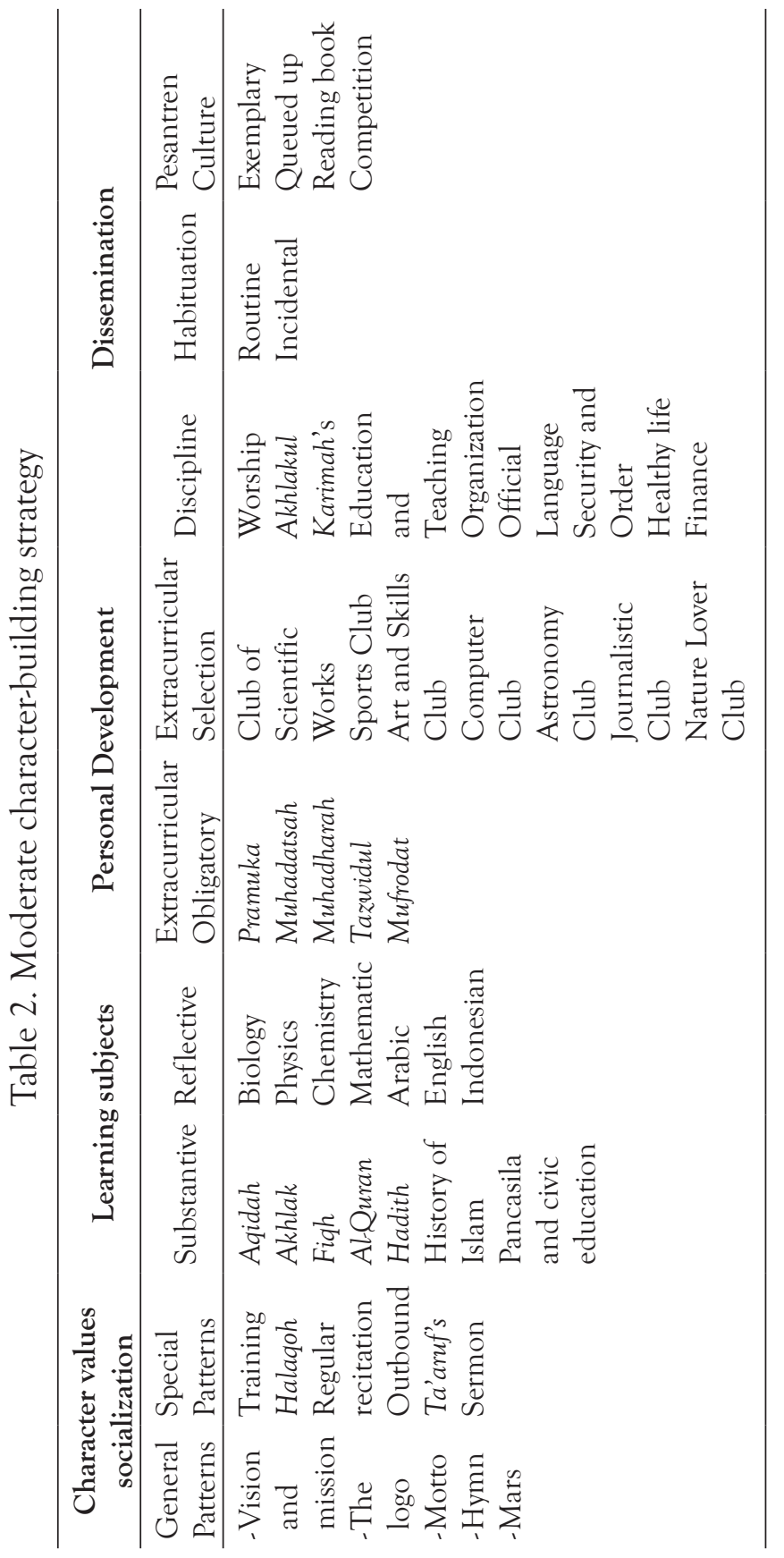




\section{Conclusion}

Pesantren Assalaam's 24-hour education and learning process is challenged by globalization and Indonesian Muslim dynamics. Pesantren Assalaam combines modern education with traditional pesantren traditions. Al muhafadhatu'ala al-qadim as-sholih wal akhdu bi al-jadid al-ashlah is implemented proportionally to spread moderate character education.

The moderate character building conducted in pesantren Assalaam is in line with its vision and mission and involves all components and stake holders in the pesantren. In doing so, moderate character building is carried out through discipline (al-indhibath), habituation (as-Sajiyyah), and the pesantren culture (an-nadzhmu al-ma'had) approach.

The main character values that underpin and as the reference for all activities in pesantren Assalaam are explored and built based on the Quran and Hadits (religious foundation), the founding fathers big dream (historical foundation), the pesantren vision (institutional foundation), the pesantren and broader Indonesian pesantren empirical experiences (empirical foundation), and the challenges and needs of the modern-dynamics era (social foundation and technological science).

Pesantren Assalaam formulates several main values as the reference in building moderate character in the education process, which are implemented in the five basic abilities of the students and codified as the Keassalaaman principle, which covers knowledgeable in science and technology, well-understood their Islamic teachings, having good deeds, preaching Islam, and having the spirit of a leader.

This study helps researchers and policy makers understand the dynamics of pesantren learning and education, particularly in relation to moderate character building. This paper also recommends more research on the method's effectiveness in developing students' moderate character in Indonesian pesantren. 


\section{Bibliography}

Al-Attas, Syed.M.N. Islam and Secularism. Kuala Lumpur: ISTAC, 2003.

Al-Attas, Syed M.N. The Concept of Education in Islam. Petaling Jaya: ABIM, 1980. Al-Jabiri, M.A. Post Tradisionalisme Islam. Yogyakarta: LKiS, 2000.

An-Najjar, A.M. Fi Figh al-Tadayyun, Fahman wa Tanzilan (Pemahaman Islam, antara Rakyu dan Wahyu). Trans. Bahruddin Fanani. Bandung: PT Remaja Rosdakarya, 1997.

Antonio, Muhammad Syafi' i. Muhammad Saw the Super Leader Manager. Jakarta: Tazkia Multimedia \& Pro LM Centre, 2007.

Asy'arie, Musa. Pendidikan Sekolah Kita Antirealitas. dalam Dinamika Kebudayaan dan Problem Kebangsaan. Yogyakarta: Lembaga Studi Filsafat Islam, 2011.

Azra, Azyumardi. Pendidikan Islam: Tradisi dan Modernisasi Menuju Milenium Baru. Jakarta: Kalimah Press, 2001.

Battisch, V. Character Education, Prevention and Positive Youth Development. Columbia: University of Missouri, 2002.

Brigham, J.C. Social Psychology. New York: Harper Collins Publisher Inc., 1991.

Dhofier, Zamakhsyari. Tradisi Pesantren: Studi tentang Pandangan Hidup Kyai. Jakarta: LP3ES,1994.

Fananie, R.Z. Pedoman Pendidikan Modern. Jakarta: Fananie Center, 2010.

Federspiel, Howard M., "The Muhammadijah: A Study of an Orthodox Islamic Movement in Indonesia”, Indonesia, Number 10 (1970): 57-79.

Feist, J. \& Feist, G.J. Theories of Personality. Sixth ed. New York: McGraw-Hill, 2006. Gunarsa, S.D. Konseling dan Psikoterapi. Jakarta: PT BPK Gunung Mulia, 1992.

Hanafi, Hasan. Al-Turāth wa al-Tajdìd: Mawqifunā min al-Turāth al-Qadīm. Beirut: al-Muassasah al-Jam'iyyah li al-Dirāsāt wa al-Nashr wa al-Tawzi'; Yogyakarta: Titian Ilahi Press dan Pesantren Pascasarjana Bismillah Press, 2002.

Hasib, K. Pendidikan Karakter, Mau Kemana? [Online], 2011. Available at: http://www.hidayatullah.com/artikel/tsaqafah/read/2011/07/15/2201/ pendidikan-karakter-mau-kemana.html\#.U8WIbkDKtFs

House, R.J. Culture Leadership and Organizations: The Globe Study of 62 Societies. California: Sage Publications, 2004.

Huda, M., "Pendidikan Karakter dalam Sebuah Festival", Jawa Pos, 7 Juli 2010. Husaini, Adian, "Pendidikan Karakter Berbasis Ta'dib", Tsaqafah Jurnal Peradaban Islam, Volume 9, No. 2 (2013): 371-394.

Kesuma, D., Triatna, C., \& Permana, J. Pendidikan Karakter, Kajian Teori dan Praktik di Sekolah. Bandung: PT Remaja Rosdakarya, 2011.

Koentjaraningrat. Pengantar Ilmu Antropologi. Jakarta: Rineka, 2009. 
Lefrancois, G.R. Theories of Human Learning, Kro's Report. California: Brook/Cole Publishing Company, 1995.

Lickona, T. Educating for Character, How Our Schools Can Teach Respect and Responsibility. New York: Bantam Books, 1992.

Lickona, T., Schaps, E. \& Lewis, C. 11 Principles of Effective Character Education. Washington: Character Education Partnership, 2010.

Madjid, Nurcholish. Bilik-bilik Pesantren, Sebuah Potret Perjalanan. Jakarta: Paramadina, 1997.

Mariana, R. et al. Pengelolaan Lingkungan Belajar. Jakarta: Kencana, 2010.

Megawangi, Ratna. Pendidikan Karakter Solusi yang Tepat untuk Membangun Bangsa.

Cimanggis: Indonesia Heritage Foundation, 2007.

MoRA. Moderasi Beragama. Jakarta: Litbang Kemenag, 2019.

Mulyasa, E. Pengembangan dan Implementasi Kurikulum 2013. Bandung: PT Remaja Rosdakarya, 2013.

Muslich, M. Pendidikan Karakter: Menjawab Tantangan Krisis Multidimensional. Jakarta: Bumi Aksara, 2011.

Scerenko, L.C. Values and Character Education Implementation Guide. Atlanta: Departement of Education, 1997.

Sargent \& William. S. Social Psychology: An Introduction to the Study of Human Relations. New York: Ronald Press, 1958.

Setiawan, M.N.K., "KH. A. Wahid Hasyim (1914-1953); Tokoh Nasional dari Tradisi Pesantren”, in KH. Wahid Hasyim Sejarah, Pemikiran, dan Baktinya bagi Agama dan Bangsa. Jombang: Pesantren Tebuireng, 2011: 11-20.

Sudiyono, L\& Karmini, N. W., "Character Education Through Social Guidence For Student", Journal Talent Development E Excellence, Vol. 12, No. 1 (2020): 284-298.

Surya, M. Teori-teori Konseling. Bandung: Bani Quraisy, 2003.

Suwija, I.N, Darmada, I.M, Mulyawan, I.N.R, \& Suryasa, W. "Character Education Value of Ending King Sexual Cruelty on Ni Dyah Tantri Story”, Journal Talent Development Eु Excellence, Vol. 12, No. 2 (2020): 737-745.

Pritchard, I., "Character Education: Research, Prospects and Problems", American Journal of Education, Vol. 96, No. 4 (1988): 469-495.

Wahid, Abdul. Menggerakkan Tradisi: Esai-Esai Pesantren. Yogyakarta: LkiS, 2001 Wahid, Abdurrahman. Menggerakkan Tradisi: Esai-Esai Pesantren. Yogyakarta: LkiS, 2001.

Wynne, E \& Walberg, H. (Eds). Developing Character: Transmitting Knowledge. Posen: ARL, 1984. 
IJIMS: Indonesian Journal of Islam and Muslim Societies, Volume 11, Number 2, December 2021: 185-212

Yayasan Majelis Pengajian Islam. Keassalaman. Surakarta: PPMI Assalam Surakarta, 2011.

Yin, R.K. Case Study Research Design and Methods. Washington: Cosmos Corporation, 1989.

Ziemek, Manfred. Pesantren dalam Perubahan Sosial. Trans. Butche B. Soendjojo. Jakarta: Perhimpunan Pengembangan Pesantren dan Masyarakat, 1986. 